DOI: $10.2478 / \mathrm{v} 10014-009-0008-\mathrm{y}$

Agrovoc descriptors: national parks, public opinion, social values, surveys, highlands, alps, quality of life, living standards environmental protection, employment

\title{
Local inhabitants' opinion about quality of life inside and outside the Triglav National Park
}

\author{
Jana ZURC ${ }^{1}$, Andrej UDOVČ $\check{C}^{2}$
}

Received September 23, 2008; accepted April 2, 2009.

Delo je prispelo 23. septembra 2008; sprejeto 2. aprila, 2009.

\section{ABSTRACT}

Article presents results of a research made among local inhabitants inside and outside the Triglav National Park in Slovenia. Including the local inhabitants in the decision making process should have positive influence on further progress of the area. A poll was made among 200 residents for this purpose, in which we wanted to get inhabitants' opinion of quality of life in the area where they live. Results indicate that $36 \%$ of interviewees agree that their quality of life is good and $12 \%$ claim that it is very good. $68 \%$ of inhabitants strongly agree and $25 \%$ agree that their area of living needs better employment chances.

Key-words: national park, quality of life, local inhabitants' opinion, Slovenia.

\section{IZVLEČEK}

\author{
MNENJE LOKALNIH PREBIVALCEV O KVALITETI \\ ŽIVLJENJA V IN IZVEN TRIGLAVSKEGA \\ NARODNEGA PARKA V SLOVENIJI
}

Članek predstavlja rezultate raziskave, ki je bila izvedena med lokalnim prebivalstvom, ki živijo $\mathrm{v}$ in izven Triglavskega narodnega parka $\mathrm{v}$ Sloveniji. Vključitev lokalnega prebivalstva $\mathrm{v}$ proces soodločanja naj bi pozitivno vplivala na nadaljnji razvoj območja. $V$ ta namen je bila izvedena anketa med 200 anketiranci s katero smo želeli pridobiti mnenje prebivalcev o kvaliteti življenja $\mathrm{v}$ območju, kjer prebivajo. Rezultati kažejo, da se 36\% anketiranih prebivalcev strinja, da je kvaliteta življenja v območju kjer prebivajo dobra, $12 \%$ jih meni, da je kvaliteta življenja zelo dobra. Kar 68\% anketiranih prebivalcev se zelo strinja in $25 \%$ se strinja s trditvijo, da njihovo območje potrebuje boljše možnosti zaposlovanja.

Ključne besede: narodni park, kvaliteta življenja, mnenje lokalnih prebivalcev, Slovenija.

\section{INTRODUCTION}

Different experts admit that social factor has a very important role in protected area management (Sewell, 1973, 1974; Grumbine, 1994; Christensen et al., 1996; Trakolis, 2001; Pavlikakis and Tsihrintzis, 2001, 2003a, 2006, Elliott and Udovč, 2005, Rodela and Udovč, 2008). Inhabitants' participation in decision making process and inclusion of their preferences, needs and activities into the management plans ensure their realization and expected results. Research work on social and economic status as well as on preferences and perceptions of the people should be beforehand of all other activities, to avoid the disagreements. The local inhabitants have to be part of the integrated management method (Pavlikakis and Tsihrintzis, 1999, 2000, 2001, 2003a, 2003b, 2006). Also the IUCN (International Union for Conservation of Nature and Natural Resources) believes that local inhabitants taking

\footnotetext{
${ }^{1}$ University of Ljubljana, Biotechnical Faculty, Department of Agronomy, Jamnikarjeva 101, SI-1000 Ljubljana, Slovenia, e-mail: jana.zurc@bf.uni-lj.si

${ }^{2}$ ibid., email: andrej.udovc@bf.uni-lj.si
} 
part and having equal rights in the decision making process, is of great significance (IUCN, 1993).

The experts began to discover the importance and role of local inhabitants in projects on development of rural societies not earlier than in 70'. There are more reasons for this and they originate first of all from the fact, that the local inhabitants know, see and understand their area better than anybody else (Barbič, 1991).

Inhabitants should be directly attracted to participate in all preparation phases and in the carrying out of the development programs. "Bottom up" development approach, which is founded on democratic enforcements of developing interests and initiatives, enables realizing the principle of subsidiary in managing the public affairs, releases the personal initiative of local inhabitants and strengthens the mutuality and essential cooperation at performing development activities (Kovačič, 2000, Perpar and Udovč, 2007). It can be said, that the basic condition for success of any rural development project is incorporation of local inhabitants needs (Barbič, 1991, Barbič et al., 2004, Udovč and Perpar, 2007).
Slovenian rural development policy for the period 20072013 forms three main axes, which are aimed to increase the competitive position of agriculture and forestry, improvement of environments condition on countryside and improvement of life quality and stimulation of various economic activities in countryside. Single axes include measures for reaching the set goals, supported with financial sources from European agricultural fund for rural development. To the listed axes counts also the methodological axis LEADER, with the "bottom up" approach, what encourages local activity at rural development (Program razvoja ..., 2008; Projekt ..., 2008).

Purpose of this article is to represent local inhabitants' perception about quality of life in the area where they live and their opinion, what this area needs for better quality of life. The main question was, if there are any differences in quality of life between people who live within the Triglav National Park and those who live outside the protected area.

\section{MATERIALS AND METHODS}

Data for the analysis were collected within the project "Triglavski narodni park - Analiza izkušenj lokalnega prebivalstva" where we using questionnaire (Rodela, 2007) with 200 randomly chosen local inhabitants within and outside the Triglav National Park. Data assembling took place from $5^{\text {th }}$ till $21^{\text {st }}$ of September 2006. Inside the Triglav National Park 46 residents from 19 villages were questioned, which represents $23 \%$ of whole sample. In areas around the Triglav National Park 154 residents from 36 villages were questioned and that represents $77 \%$ of the whole sample. Comparing the area of living there was 80 inquiries made in Posočje, 80 in Kranjska Gora and Bled area and 40 in Bohinj area. Questioned people were chosen randomly, by considering next criteria: they had to be full aged, native or having a residence of living in that area, which they define as their home. At poll we wanted to equally include people employed in different economic spheres, namely farmers, tourism contractors, people employed in tourism, other contractors and craftsmen, people employed in bigger and smaller enterprises and people employed in public institutions.

People, who took part in the poll, were asked about following socio-demographic characteristics: town of residence, gender, year of birth, number of members in housekeeping and number of children, legal status, employment status, place of work and education.
The people were also asked to estimate quality of life in the area they live in. Quality of life of local inhabitants was studied with following variables: employment chances, rural development policy, chances of adults educations, conditions for establishing an enterprise or trade activity, conditions to employ small contractors and tradesmen, road connection, public transport access, internet and telephone access, possibilities for entertainment and social connections, medical care, caring for residents needs from local communities and state institutions, cooperation between local contractors, tradesmen and commune and coordination/leadership. Statements about quality of life were rated with seven degree Likert scale, where mark 1 signified, that people totally disagree with the statement and mark 7 signified, that they strongly agree with the statement.

Statistic analysis of the answers was made with use of the SPSS 15.0 programme for Windows. We calculate basics statistic parameters for each variable. Where necessary we joined marks 2 and 3 and marks 5 and 6 on the 1 to 7 scale, because of small number of answers. Differences were tested with Chi-square test.

\section{RESULTS AND DISCUSSION}

Number of people questioned was equally distributed between women $(54.5 \%)$ and men $(45.5 \%)$. Majority of questioned were aged between 26 and 55 years $(74.5 \%)$, and belong to the most active part of the population. Education level indicates that the majority of interviewees have secondary school education (64.5\%). 
As for the employment status $14 \%$ of people included in poll were farmers, $32.5 \%$ employed in tourism and 53.5 employed in other economic branches. $38.5 \%$ of questioned people live in families with 2 members, $25.5 \%$ in families with 3 members and $25.5 \%$ with 4 members. More than one half of the people included in the poll $(53 \%)$ did not have any children. $21 \%$ of asked have only one child and $18.5 \%$ had two children. $61 \%$ of questioned inhabitants were married, $18.5 \%$ were single and $16.5 \%$ lived together with a partner. $88.5 \%$ of people, who took part in the poll, work in the same commune as they live in and $7 \%$ drive on work to the neighbouring commune.

Results show (Picture 1), that $36 \%$ of people, who took part in the poll, agree with the statement, that the quality of life in their area is good, and $12 \%$ believe that quality of life is very good. $15 \%$ of people believe that the quality of life is bad and $9.5 \%$ think that it is very bad.

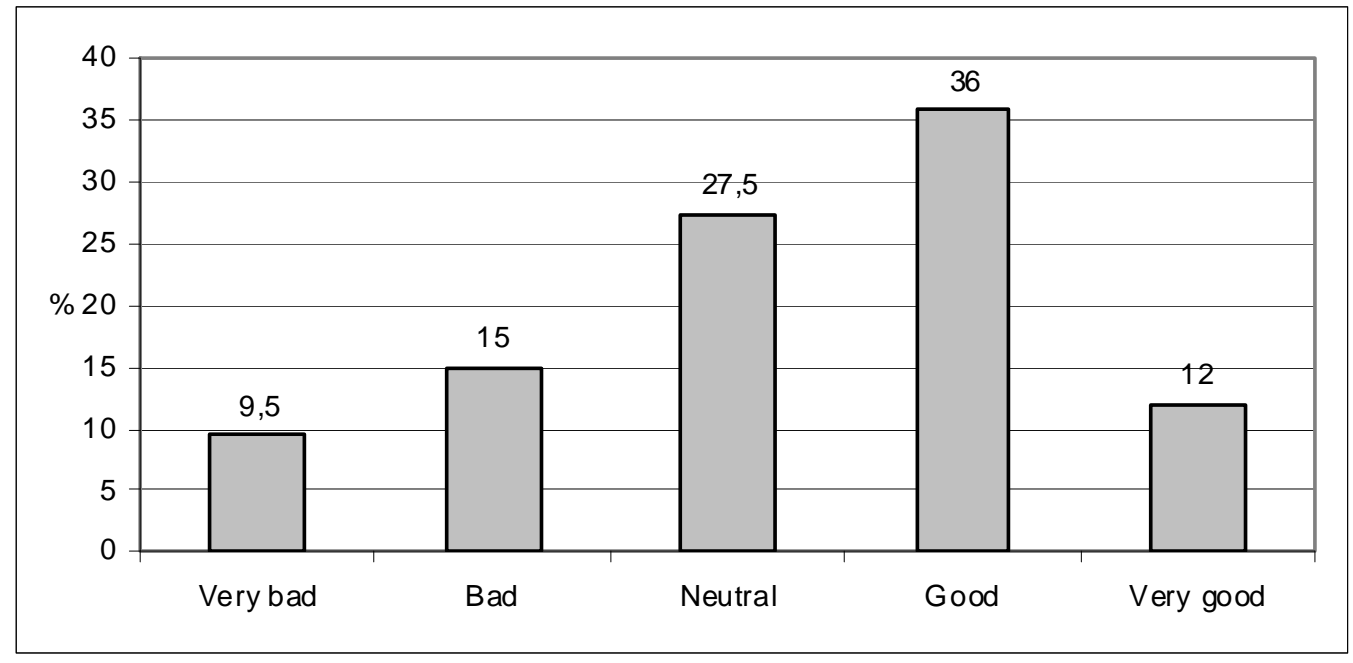

Picture 1: Assessment of quality of life by interviewees, 2006

Inhabitants agree that the area needs above all better employment chances (93\%), better rural development policy $(88 \%)$, more care from state institutions $(85 \%)$, better employment chances for people with college and high education (84\%), more care for inhabitants' needs from local communities $(83 \%)$, better coordination/leadership $(81 \%)$ and better road connections $(80.5 \%)$.

As many as $68 \%$ of people taking part in the poll strongly agree and $25 \%$ agree with the statement, that their area needs better employment chances. That area needs better employment chances for high educated people and people with college strongly agree 64\% and agree $20 \%$ of the people questioned.

Additional comments were mostly given by the question about quality of road connections. Residents mentioned above all that the local roads are in bad conditions. Inhabitants of Bled have exposed the problem of increased traffic in mornings and afternoons rush hours and the need for building a bypass around the city centre. In tourist places, as for example Bled, inhabitants think, that above all in wintertime there are not enough opportunities for social interactions and entertainment among locals. What concerns the medical care, inhabitants warn that in the tourist season, because of so many tourists, the need for medical service is higher. Access to public transport is important above all for schoolchildren and students. Public transport (bus, train) should be better connected with school centres and first of all trains should drive more regularly in hours before and after classes. In certain areas there is still bad internet access.

We also asked interviewees if, beside what was already listed needs, they need anything else. 24 or $12 \%$ of people included in the poll answered positively and mentioned:

- bio shop

- increased environment protection

- better adoption to peoples' needs for example with setting up a college,

- more people with feeling for countryside, for preserving settlement of countryside,

- bookstore and sports equipment shop,

- development strategy,

- cycling paths, 
Table 1: Agreement of the interviewees with the given statements

\begin{tabular}{|c|c|c|c|c|c|c|c|c|c|c|}
\hline & \multicolumn{2}{|c|}{$\begin{array}{l}\text { I do not agree at } \\
\text { all }\end{array}$} & \multicolumn{2}{|c|}{ I do not agree } & \multicolumn{2}{|c|}{ Undecided } & \multicolumn{2}{|l|}{ I agree } & \multicolumn{2}{|c|}{ I strongly agree } \\
\hline & $\mathrm{N}$ & $\%$ & $\mathrm{~N}$ & $\%$ & $\mathrm{~N}$ & $\%$ & $\mathrm{~N}$ & $\%$ & $\mathrm{~N}$ & $\%$ \\
\hline $\begin{array}{l}\text { Better employment } \\
\text { chances }\end{array}$ & 3 & 1.5 & 4 & 2.0 & 7 & 3.5 & 50 & 25.0 & 136 & 68.0 \\
\hline $\begin{array}{l}\text { Better employment } \\
\text { chances for high } \\
\text { educated people and } \\
\text { people with college }\end{array}$ & 4 & 2.0 & 7 & 3.5 & 21 & 10.5 & 40 & 20.0 & 128 & 64.0 \\
\hline $\begin{array}{l}\text { Better rural } \\
\text { development policy }\end{array}$ & 4 & 2.0 & 4 & 2.0 & 16 & 8.0 & 51 & 25.5 & 125 & 62.5 \\
\hline Better road connection & 11 & 5.5 & 11 & 5.5 & 17 & 8.5 & 40 & 20.0 & 121 & 60.5 \\
\hline $\begin{array}{l}\text { More care from side of } \\
\text { public institutions }\end{array}$ & 5 & 2.5 & 6 & 3.0 & 19 & 9.5 & 56 & 28.0 & 114 & 57.0 \\
\hline $\begin{array}{l}\text { More care for } \\
\text { inhabitants' needs from } \\
\text { side of local } \\
\text { communities }\end{array}$ & 4 & 2.0 & 7 & 3.5 & 23 & 11.5 & 68 & 34.0 & 98 & 49.0 \\
\hline $\begin{array}{l}\text { Better conditions for } \\
\text { small enterprises and } \\
\text { craftsmen }\end{array}$ & 3 & 1.5 & 11 & 5.5 & 32 & 16.0 & 56 & 28.0 & 98 & 49.0 \\
\hline $\begin{array}{l}\text { Better } \\
\text { coordination/leadership }\end{array}$ & 10 & 5.0 & 8 & 4.0 & 20 & 10.0 & 65 & 32.5 & 97 & 48.5 \\
\hline Better medical care & 24 & 12.0 & 13 & 6.5 & 25 & 12.5 & 44 & 22.0 & 94 & 47.0 \\
\hline $\begin{array}{l}\text { Better conditions for } \\
\text { establishing an } \\
\text { enterprise or trade } \\
\text { activity }\end{array}$ & 7 & 3.5 & 10 & 5.0 & 38 & 19.0 & 56 & 28.0 & 89 & 44.5 \\
\hline $\begin{array}{l}\text { Better cooperation } \\
\text { between local } \\
\text { contractors and } \\
\text { commune }\end{array}$ & 8 & 4.0 & 6 & 3.0 & 45 & 22.5 & 57 & 28.5 & 84 & 42.0 \\
\hline $\begin{array}{l}\text { More chances for social } \\
\text { life and entertainment }\end{array}$ & 28 & 14.0 & 19 & 9.5 & 19 & 9.5 & 60 & 30.0 & 74 & 37.0 \\
\hline $\begin{array}{l}\text { Better cooperation } \\
\text { between local } \\
\text { contractors and } \\
\text { tradesmen }\end{array}$ & 9 & 4.5 & 10 & 5.0 & 50 & 25.0 & 61 & 30.5 & 70 & 35.0 \\
\hline $\begin{array}{l}\text { Better chances for adult } \\
\text { education }\end{array}$ & 18 & 9.0 & 16 & 8.0 & 25 & 12.5 & 74 & 37.0 & 67 & 33.5 \\
\hline $\begin{array}{l}\text { Improvement of access } \\
\text { to public transport }\end{array}$ & 37 & 18.5 & 18 & 9.0 & 24 & 12.0 & 54 & 27.0 & 67 & 33.5 \\
\hline $\begin{array}{l}\text { Better access to } \\
\text { telephone, post and } \\
\text { internet }\end{array}$ & 74 & 37.0 & 28 & 14.0 & 21 & 10.5 & 37 & 18.5 & 40 & 20.0 \\
\hline
\end{tabular}

- more help with setting new activities, preparation of documentation and financial support,

- finances, that the road infrastructure, public transport, telecommunications, etc would better function - better municipal infrastructure,

- better feeling of a collective, help from craftsmen and contractors and help from commune by different activities,

- better chances for leisure time activities (for example swimming pool),

- better coherence between economic subjects in general, to attract people to stay here with assuring more employment opportunities,

- the main problem is, that the area needs, as all the other areas in the country, better legislation system, the system of non-refundable funds are not big enough to help people and they should devote bigger part of the budget for countryside,

- better railway connections,

- more winter tourist, acceleration of winter tourism,

- same chances for countryside and town,

- better social standard, 
- $\quad$ better scholarship policy, because of the remoteness from school centres more schoolchildren and students should get scholarships,

- income tax relieves,

- shop,

- more provisions and technical stores,

We were also interested if there are any significant statistical correlations between place of living (Posočje, Bled, Kranjska Gora and Bohinj), area of living (within or outside the protected area), gender, age and education.

Comparison of quality of life and area of living (in or outside the protected area) (Table 2) showed that $13 \%$ of people living outside the Triglav National Park and $8.7 \%$ of those living within the Triglav National Park believe that the quality of life is very good. That the quality of life is good think $38.3 \%$ of questioned living outside the Triglav National Park and $28.3 \%$ of those living within the Triglav National Park. 13\% of questioned living within the Triglav National Park and $8.4 \%$ of those living outside the Triglav National Park think that their quality of life is very bad. That the quality of life is bad think $6.5 \%$ of questioned living within the Triglav National Park and $17.5 \%$ outside the Triglav National Park $(p=0.030)$. Results show, that the people who live inside the Triglav National Park are less satisfied with their quality of life than those who live outside the park (37\% versus $51.3 \%$ ).

Table 2: Quality of life compared to area of living (within or outside protected area)

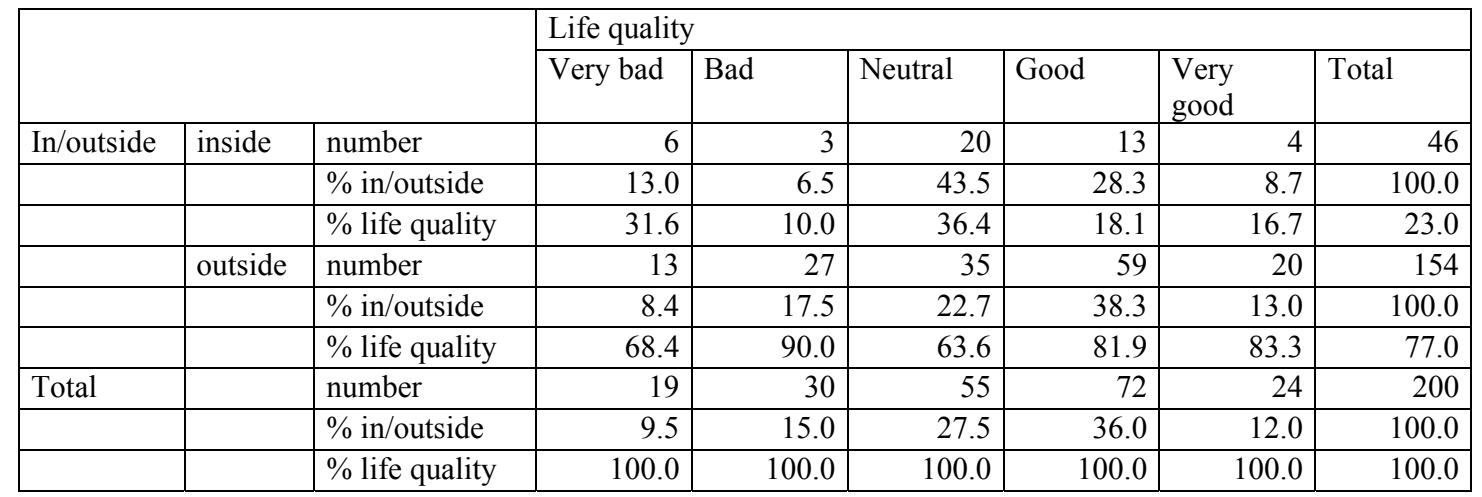

Statistically significant is also the relation between the area of living (inside or outside the Triglav National Park) and opinion of residents that the area needs better medical services $(p=0.005)$. That the area needs better medical services in higher number agree inhabitants inside the Triglav National park $(91.3 \%)$, than those living outside the Triglav National Park (62.3\%). As much as $65.2 \%$ of people taking part in the survey within the Triglav National Park strongly agree and $26.1 \%$ agree that the area needs better medical services. $41.6 \%$ of questioned outside the protected area strongly agree that the area needs better medical services, where $20.8 \%$ of them this statement marked with agree.

Those living inside the Triglav National Park think that this area needs better access to the telephone, post and internet $(60.9 \%)$. The same opinion has $31.8 \%$ of people living outside the Triglav National Park, what is a significant difference $(\mathrm{p}=0.004)$.

$69.6 \%$ of questioned, living inside the Triglav National Park, think that their area needs better coordination/leadership. The same opinion has $84.4 \%$ of those living outside the Triglav National Park. $19.5 \%$ of people questioned inside the Triglav National Park and just $5.8 \%$ of people questioned outside the Triglav National Park disagree with the statement that their area needs better coordination/leadership. In spite of big part of those who have the wish for better coordination/leadership, we see that the part of those is smaller in the Triglav National Park as outside the protected area $(\mathrm{p}=0.044)$, perhaps because the protected area has some legally defined structures.

The results also show, that people living within the Triglav National Park (78.3\%) miss chances for social interactions and entertainment much more than people living outside the Triglav National Park (63.6\%) $(\mathrm{p}=0.053)$.

Chi-square test shows that there is statistically significant relation between quality of life and the place of residence ( $\mathrm{p}=0.008$ ). $21.3 \%$ of questioned from Bled and Kranjska Gora think, that the quality of life is very good. That the quality is good agree further $40 \%$ of people included in the poll living on Bled and Kranjska Gora area. Unhappy with life quality are as much as $32.5 \%$ of people from Posočje (Table 3 ). 
Table 3: Quality of life regarding the place of living

\begin{tabular}{|c|c|c|c|c|c|c|c|c|}
\hline & \multicolumn{6}{|c|}{ Quality of life } \\
\hline & & & Very bad & $\mathrm{Bad}$ & Neutral & Good & Very good & Total \\
\hline \multirow{9}{*}{$\begin{array}{ll}\begin{array}{l}\text { Place } \\
\text { living }\end{array} & \text { of } \\
\end{array}$} & Posočje & number & 8 & 18 & 25 & 25 & 4 & 80 \\
\hline & & $\%$ area & 10.0 & 22.5 & 31.3 & 31.3 & 5.0 & 100 \\
\hline & & $\begin{array}{l}\% \text { quality } \\
\text { of life }\end{array}$ & 42.1 & 60.0 & 45.5 & 34.7 & 16.7 & 40.0 \\
\hline & $\begin{array}{l}\text { Bled, } \\
\text { Kranjska } \\
\text { Gora } \\
\end{array}$ & number & 4 & 8 & 19 & 32 & 17 & 80 \\
\hline & & $\%$ area & 5.0 & 10.0 & 23.8 & 40.0 & 21.3 & 100 \\
\hline & & $\begin{array}{l}\% \text { quality } \\
\text { of life }\end{array}$ & 21.1 & 26.7 & 34.5 & 44.4 & 70.8 & 40.0 \\
\hline & Bohinj & \begin{tabular}{|l|} 
number \\
\end{tabular} & 7 & 4 & 11 & 15 & 3 & 40 \\
\hline & & $\%$ area & 17.5 & 10.0 & 27.5 & 37.5 & 7.5 & 100.0 \\
\hline & & $\begin{array}{l}\% \text { quality } \\
\text { of life }\end{array}$ & 36.8 & 13.3 & 20.0 & 20.8 & 12.5 & 20.0 \\
\hline \multirow[t]{3}{*}{ Total } & & number & 19 & 30 & 55 & 72 & 24 & 200 \\
\hline & & $\%$ area & 9.5 & 15.0 & 27.5 & 36.0 & 12.0 & 100.0 \\
\hline & & $\begin{array}{l}\text { \% quality } \\
\text { of life }\end{array}$ & 100.0 & 100.0 & 100.0 & 100.0 & 100.0 & 100.0 \\
\hline
\end{tabular}

There is statistically significant relation between place of living and the need for better employment chances $(p=0.020)$. In all places residents strongly agree that the area needs better employment chances. Such answer gave $78.8 \%$ of questioned from Posočje, $75 \%$ of questioned from Bohinj and 53.8\% living in Bled and Kranjska Gora.

In Bohinj $85 \%$ of interviewees strongly agree and $12.5 \%$ agree with the statement, that their area needs better rural development policy. That area needs better rural development policy strongly agree 58.8\% and agree $30 \%$ residents from Posočje and also strongly agree $55 \%$ and agree $27.5 \%$ questioned from Bled and Kranjska Gora. The differences among places of living are statistically significant $(\mathrm{p}=0.022)$.

As much as $87.5 \%$ of questioned from Bohinj strongly agree and $7.5 \%$ agree with statement, that the area needs better medical provision. With this statement strongly agree $37.5 \%$ and agree $33.8 \%$ questioned from Posočje. Results show that $27.5 \%$ people from Bled and Kranjska Gora thinks that their area doesn't need better medical services. The differences among places are statistically significant $(\mathrm{p}=0.000)$.

Regarding the interviewees' perception of the local leadership 25\% questioned from Bohinj, 6.3\% from Bled and Kranjska Gora and 3.8\% from Posočje do not agree with the statement, that their area needs better coordination/leadership. That the area needs better coordination/leadership agree $88.8 \%$ from Posočje,
$78.8 \%$ from Bled and Kranjska Gora and 70\% from Bohinj. The differences among places of living are statistically significant $(p=0.002)$. On the other hand there is a statistical significant difference $(p=0.061)$ in the opinion that the area needs better conditions for establishing an enterprise or trade activity. $85.1 \%$ from Posočje, 70\% from Bohinj and 61.3\% from Bled and Kranjska Gora agree with that.

Table 4 shows, that there is no statistically significant connection between the assessment of the quality of life and gender $(\mathrm{p}=0.904)$.

Results also show that $72.5 \%$ of women and $53.8 \%$ of men strongly agree with the statement, that the area needs better employment chances for high educated people and people with college. With this statement don't agree $9.9 \%$ men and just $1.8 \%$ women and the difference is statistically significant $(\mathrm{p}=0.017)$.

With the statement, that the area needs more opportunities for social interactions and entertainment agrees $78 \%$ of women and $53.9 \%$ of men. As much as $23.1 \%$ of men and just $6.4 \%$ of women don't agree with this statement at all. The difference is statistically significant $(\mathrm{p}=0.000)$.

Results show, that with the statement, that the quality of life is good, more agree younger people than older $(p=0.030)$. More than half of people included in the poll which are up to 45 years old, agree that the quality of life is good (Table 5). 
Table 4: Assessment of quality of life compared to gender

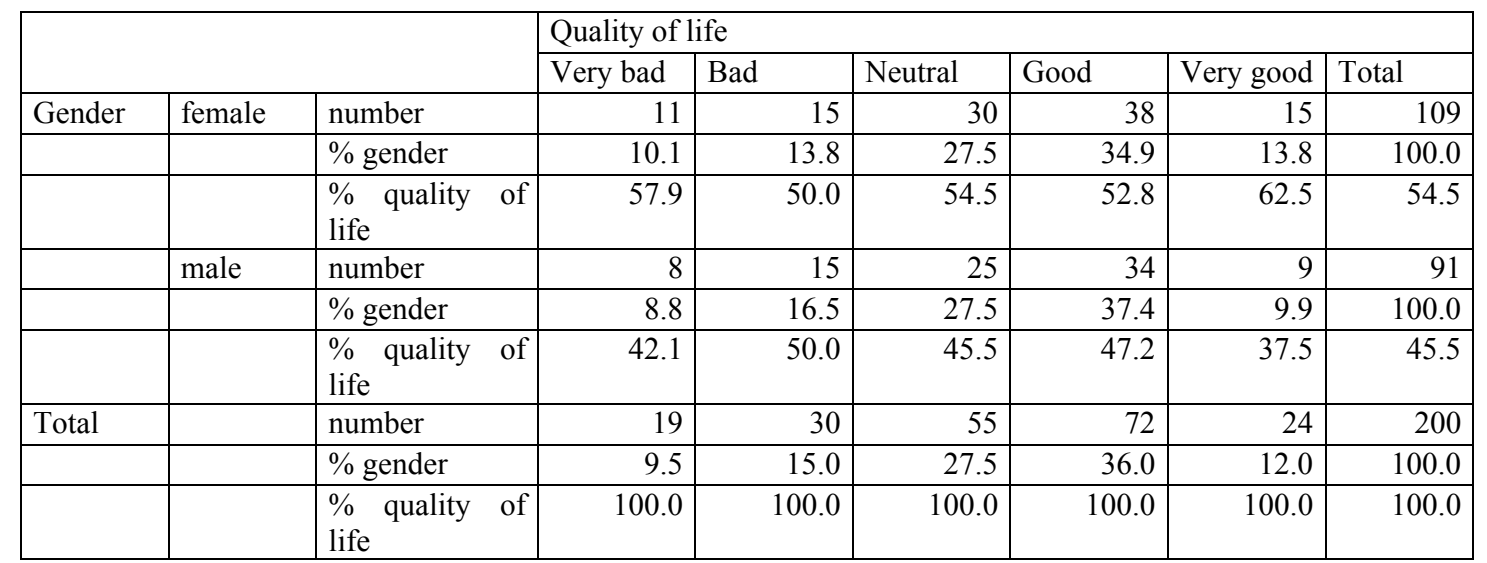

Table 5: Quality of life compared to age

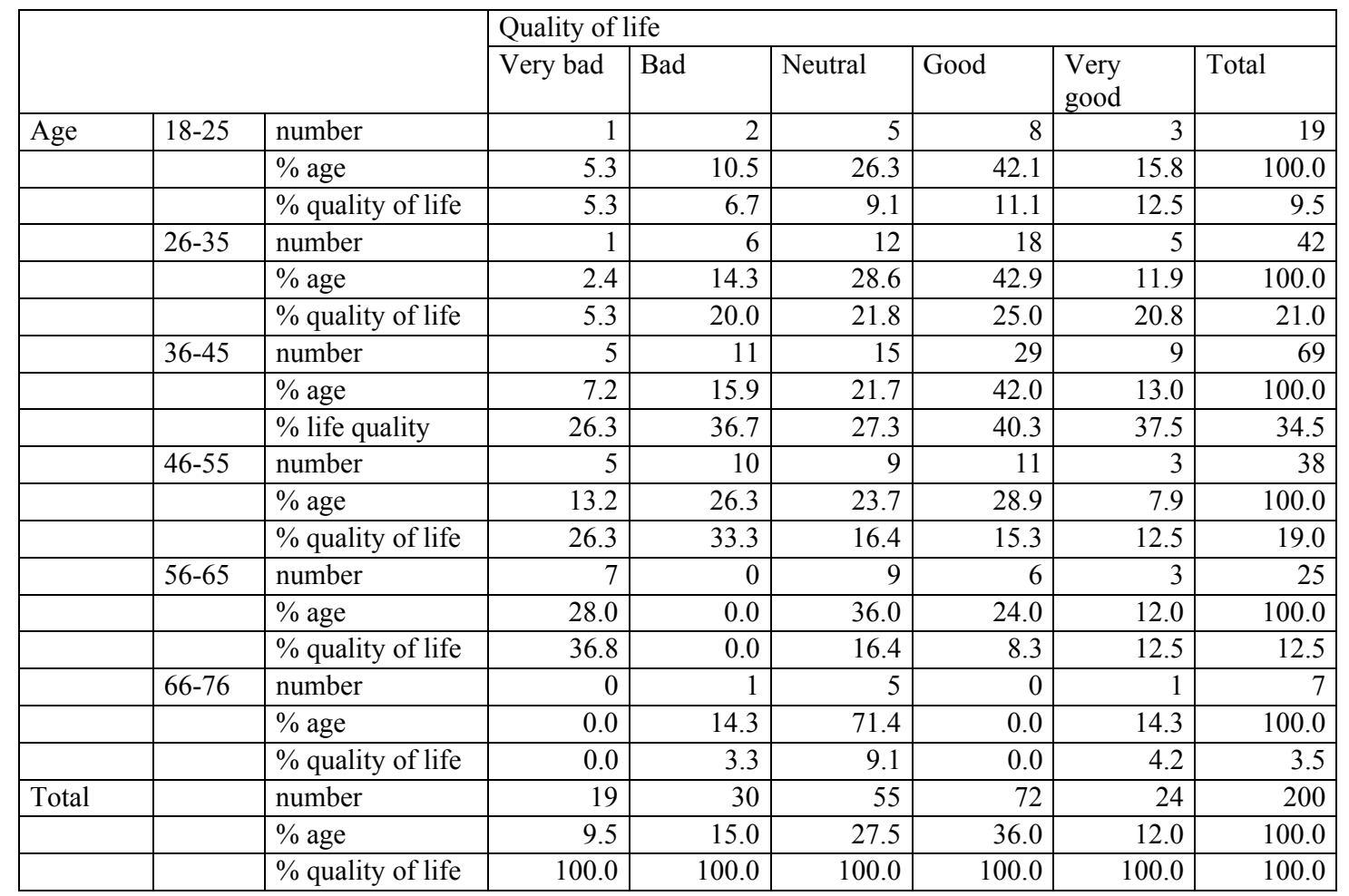

That their area needs better access to telephone, post and internet thinks 57.2\% people aged between 66 and 76 years, $47.8 \%$ people aged between 36 and 45 years, $42.1 \%$ people aged between 18 and 25 years, 35.7\% people aged between 26 and 35 years, $29 \%$ people aged between 46 and 55 years and $24 \%$ people aged between 56 and 65 years. People aged between 46 and 65 years in bigger number not agree, that the area needs better access to telephone, post and internet $(\mathrm{p}=0.054)$.

There is no statistically significant differences between quality of life and education $(p=0.478)$. Further the results show, that higher the people's education is more they agree with the statement that the area needs more attention from state institutions. Thus as much as $100 \%$ questioned with faculty, $85.8 \%$ people with vocational college, $83.7 \%$ people with secondary school and $64.3 \%$ people with elementary education think, that the area needs more attention for inhabitants' needs from state institutions $(\mathrm{p}=0.000)$.

Results show, that higher educated people in higher number agree that the area needs better coordination/leadership unlike those with elementary

Acta agriculturae Slovenica, 93 - 1, maj 2009 
education. That the area needs better coordination/leadership agree $64.3 \%$ people with elementary education, $79.3 \%$ of people with faculty,
$82.2 \%$ people with vocational college and $82.9 \%$ of people with secondary school $(\mathrm{p}=0.024)$.

\section{CONCLUSIONS}

Often the local inhabitants are excluded or overlooked at decision-making in different projects. With analyzing the perceptions and responses of local inhabitants we wanted to present the opinion of the local inhabitants living inside or outside the Triglav National Park about quality of life.

With the quality of life is satisfied almost half of the questioned. There is significant statistical difference between the quality of life and place of living (in or outside the Triglav National Park). Results show, that the people who live inside the Triglav National Park are less satisfied with their quality of life than those who live outside the park.

Regardless the place of living the inhabitants agree that their area needs above all better employment chances, better rural development policy, more care from state institutions, better employment chances for people with college and high education, more care for inhabitants' needs from local communities, better coordination/ leadership and better road connections.
There are statistical significant differences among questioned inhabitants, living inside the Triglav National Park and those living outside of it, regarding their opinions that their area needs better medical services, more opportunities for social interactions and entertainment and better access to telephone, post services and internet. In all mentioned cases the inhabitants living inside the Triglav National Park assessed the needs for listed services higher as those living outside. We believe that the identified difference can be explained with fact, that the people living outside the park live in bigger settlements or near to them, where different services are easier accessible and the supply is higher.

The results also show, that less of the interviewees living inside the park, then those who live outside of it, have the opinion that their area needs a better coordination/leadership, what we connect with the fact, that the park is legally regulated.

\section{REFERENCES}

Barbič, A. 1991. Prebivalci kot cilj in kot nosilci razvojnih projektov podeželskih skupnosti. In: Prihodnost slovenskega podeželja. Barbič, A. (ed.). Novo mesto, Dolenjska založba: 105-117.

Barbič, A., Udovč, A., Medved, A. 2004. Protection of the environment and biodiversity for sustainable future of rural areas: the case of planned Regional park Trnovski gozd, Slovenia. Sociol. sela, 42, 3/4: 277-307.

Christensen, N.L., Bartuska, M., Brown, J.H., Carpenter, S., D'Antonio, C., et al. 1996. The report of the Ecological Society of America. Committee on the scientific basic for ecosystem management. Ecol. Appl., 6, 3: 665-691.

Elliott, C., Udovč, A. 2005. Nature conservation and spatial planning in Slovenia: continuity in transition. Land use policy, 22, 3: 265-276.

Grumbine, R.E. 1994. What is ecosystem management? Conserv. Biol., 8, 1: 27-38.

IUCN (International Union for Conservation of Nature and Natural Resources). 1993. Parks for Life. Report on the IVth World Congress on National Parks and Protected Areas. IUCN, Gland, Switzerland, 252 pp.
Kovačič, M. 2000. Razvojno - tipološka členitev podeželja v Republiki Sloveniji. Ljubljana, Biotehniška fakulteta, Oddelek za agronomijo, Inštitut za agrarno Ekonomiko, $129 \mathrm{pp}$.

Pavlikakis, G.E., Tsihrintzis, V.A. 1999. Ecosystem management: a holistic approach to the management of the natural resources. In: Ecosystems and Sustainable Development II. Proceedings of the International Conference ECOSUD, 31 May-2 June. 1999. Brebbia, C.A., Uso, J.L. (eds.). WIT Press, Lemnos Greece: 385394.

Pavlikakis, G.E., Tsihrintzis, V.A. 2000. Ecosystem management: a review of a new concept and methodology. Water Resour. Manage., EWRA 14, 4: 257-283.

Pavlikakis, G.E., Tsihrintzis, V.A. 2001. Integrating humans in ecosystem management using multi-criteria decisionmaking. In: Proceedings of the Integrated Decision Making for Watershed Management Symposium: Processes and Tools, 7-9 January. 2001. Chevy Chase, USA: $600-617$. 
Pavlikakis, G.E., Tsihrintzis, V.A. 2003a. Integrating humans in ecosystem management using multi-criteria decisionmaking. J. Am. Water Resour. Assoc., 39, 2: 277-288.

Pavlikakis, G.E., Tsihrintzis, V.A. 2003b. A quantitative method for accounting human opinion, preferences and perceptions in ecosystem management. J. Environ. Manage., 68: 193-205.

Pavlikakis, G.E., Tsihrintzis V.A. 2006. Perceptions and preferences of the local population in Eastern Macedonia and Thrace National Park in Greece. Landscape and Urban Planning, 77: 1-16.

Perpar, A., Udovč, A. 2007. Rural tourism and protected areas - factors to increase resilience of rural areas [Podeželski turizem in zavarovana območja - dejavniki povečanja prožnosti podeželskih območij]. Acta agric. Slov., 89, 1: $115-128$.

Program razvoja podeželja Republike Slovenije za obdobje 2007-2013. 2. sprememba. 03.06.2008. Republika Slovenija, Ministrstvo za kmetijstvo, gozdarstvo in prehrano, 321 pp. http://www.mkgp.gov.si/fileadmin/ mkgp.gov.si/pageuploads/saSSo/PRP 2007-013/ Spremembe_PRP.pdf (30.6.2008).

Projekt statistike razvoja podeželja. Kakovost življenja in raznolikost gospodarskih dejavnosti na podeželju. 2008. Statistični urad Republike Slovenije. http://www..stat.si/ tema splosno upravno podezelje predstavitev.asp (5.5.2008).

Rodela, R. 2007. Triglavski narodni park: Analiza izkušnje lokalnega prebivalstva, končno poročilo [Triglav National Park: Analysis of local people's experience, final report]. Ljubljana, Biotehniška fakulteta, $63 \mathrm{pp}$.

Rodela, R., Udovč, A. 2008. Participation in nature protection - Does it benefit the local community? A Triglav National Park case study. International Journal of Biodiversity Science \& Management, Sapiens Publishing, Perth, UK [in print].

Sewell, W. R. D. 1973. Broadening the approach to evaluation in resources management decision-making. Journal of Environmental Management, 1: 33-60.

Sewell, W.R.D. 1974. Perceptions, attitudes and public participation in countryside management in Scotland. Journal of Environmental Management, 2: 235-257.

Trakolis, D. 2001. Perceptions, Preferences, and Reactions of Local Inhabitants in Vikos-Aoos Natinal Park, Greece. Environmental Management, 28, 5: 665- 676.

Triglavski narodni park. 2008. http://www.tnp.si (1.1.2008).

Udovč, A., Perpar, A. 2007. Role of rural tourism for development of rural areas. Journal of central european agriculture, 8, 2: 223-227. 